\title{
СИСТЕМА ЦИВІЛЬНО-ПРАВОВИХ СПОСОБІВ ЗАХИСТУ ПРАВ СПОЖИВАЧІВ ФІНАНСОВИХ ПОСЛУГ В УКРАÏHI
}

\author{
ТУПИЦЬКА Свгенія Олександрівна - кандидат юридичних наук, доцент \\ кафедри цивільного права № 2 Національного юридичного університету імені \\ Ярослава Мудрого \\ УДК: $347.451 .8(477)$ \\ DOI 10.32782/NP.2021.4.22
}

\begin{abstract}
В статье анализируется состояние гражданско-правовой зашить прав бизических лич, - заёмшиков в кредитных отношениях на современном этапе развития отечественного законодательства. Доказъвается, ито система методов защить прав потребителей бинансовъх услуг представляет собой внутренне упорядоченную совокупность всех имеюшихся средств, которье можно систематизировать методом использования разньх научныхх классификаиий. Аргументируется достоверность разделения исследуемьх способов защить на две группъ: юрисдикиионнъе и неюрисдикиионнъие. Анализируются положения нащионального гражданского законодательства и делается въгвод о вариативности способов защзить прав потребителей бинансовъгх услуг в зависимости от субъекта реализации правовой охранъл. Исследуются судебнъие, административнъле методъ и средства самозащить прав участников кредитных отношений. Обосновывается необходимость предоставления бизическому личу - потребителю бинансовых услуг определенных дополнительных правовых средств зашитьи, что приведёт к фактическому равенству участников кредитования.

Ключевъие слова: займ, кредит, защита гражданских прав, мерь гражданско-правовой ответственности, потребители бинансовъгх услуг.
\end{abstract}

Постановка проблеми

Кредиті правовідносини на сьогодні становлять собою важливу та невід'ємну складову економіки будь-якої держави. кожної країни, тому одним із важливих завдань вітчизняного законодавства є забезпечення ефективного захисту прав їх учасників. В Україні все більше набуває популярності як банківське, так і небанківське мікрокредитування, особливо серед найбільш соціально незабезпечених груп населення. Тому ця сфера потребує належного захисту прав та законних інтересів споживачів фінансових послуг, вироблення дієвих, ефективних механізмів юридичних засобів протидії недобросовісної поведінки кредитодавців. Результатом цього стане підвищення довіри населення до діяльності ринку фінансових послуг в Україні та забезпечить сприятливі умови для розвитку економіки країни у цілому.

\section{Аналіз літератури}

Теоретичним та практичним аспектам правового захисту суб'єктивних цивільних прав приділено багато уваги у науковій юридичній доктрині. Дослідженнями цих відносин займалися такі науковці, як В.В. Баранкова, М.А. Біда, Т.В. Боднар, В.І Борисова, І.В. Венедіктова, О.О. Кот, В.А Кройтор, Н.С. Кузнєцова, В.В. Надьон, В.А. Яроцький та ін. Окремі питання, що виникають під час порушення прав учасників кредитних відносин, розглядалися у працях I.A. Безклубого, А.С. Довгерта, О.С. Іоффе, А.А. Аунца, В.В. Ауця, Р.А. Майданика, В.Я. Погребняка, А.Г. Рябко, Е.О. Тупицької, Е.О. Харитонова, Ю.І. Чалого, Я.М. Шевченко та ін. Водночас наукових досліджень питань сис- 


\section{Цивільне, підприсмницьке, господарське та трудове право}

теми цивільно-правового захисту прав споживачів фінансових послуг не проводилось

Метою цієї статті є дослідження різноманітних цивільно-правових засобів, у їх цілісній системі та взаємозв'язку, що можуть використовуватись фізичними особами - споживачами у випадку порушення їхніх прав у сфері надання фінансових послуг.

\section{Виклад матеріалу}

У загальнотеоретичному аспекті поняття «система» визначають як певну сукупність встановлених, взаємопов'язаних елементів, яка утворюється з їхньої множинності. Загальноприйнятим у науці цивільного права визначенням поняття «захисту» 6 його розуміння, як сукупності дій, спрямованих на попередження, припинення та відновлення порушених суб'єктивних прав учасників цивільних відносин. Під способом захисту суб'єктивних цивільних прав розуміються закріплені законом матеріально-правові засоби примусового характеру, за допомогою яких провадиться відновлення (визнання) порушених (оспорюваних) прав і вплив на правопорушника.

Конституцією України гарантується, що кожна особа має право на захист свого порушеного права чи інтересу, у випадку, якщо це не завдає шкоди іншим учасникам суспільних відносин та не суперечить принципам справедливості, добросовісності та розумності. Відповідно до положень Цивільного кодексу України систему цивільно-правових способів захисту утворюють сукупність засобів, які реалізуються в межах компетенції відповідного владного органу. Так, наприклад, у ст. 16, ст. 17 і ст. 18 ЦК України встановлюються повноваження органів державної влади, місцевого самоврядування, нотаріату та суду щодо здійснення захисту прав учасників цивільних відносин. Водночас статтею 19 ЦК України передбачається можливість правомочної особи самостійно вчиняти дії, спрямовані на попередження, захист та відновлення своїх прав та охоронюваних законом інтересів. Сказане свідчить, що до системи захисту цивільних прав включаються також і міри так званого «самозахисту», що відповідають змісту порушеного суб'єктивного права та не перевищують меж, встановлених законодавством. У свою чергу, залежно від наданих конкретному суб'єкту захисту повноважень, законодавством проводиться окремий поділ судових, адміністративних та інших способів захисту. [9, с.28].

На сьогодні в Україні існує достатньо дієва система не тільки державних, але й інших інституцій, які здійснюють захист прав учасників кредитних правовідносин - споживачів фінансових послуг. Серед державних правозахисних органів можна виділити адміністративні, які реалізують свої правомочності в межах наданих їм законодавством повноважень, що спрямовані на усунення правопорушень в сфері кредитування та відновлення суб'єктивних прав їх учасників. Так, у Національному банку України діє структурний підрозділ - спеціальне Управління захисту прав споживачів фінансових послуг. Також до адміністративних органів можна віднести Національну комісію з цінних паперів та фондового ринку, Національну комісію, що здійснює державне регулювання у сфері ринків фінансових послуг, та ін. Наступними державними правоохоронними органами є інституції, що здійснюють захист прав та законних інтересів суб'єктів кредитування від незаконних посягань - запобігання, припинення та розслідування правопорушень [3], такі, як поліція, Служба національної безпеки України або Державне бюро розслідувань. Убачається, що сюди також належить й органи, що надають юридичну допомогу споживачам фінансових послуг, а саме: адвокати, нотаріуси тощо. Окремо слід виділити судові органи, які здійснюють захист прав учасників кредитних відносин шляхом всебічного, повного та об'єктивного розгляду цивільної справи, прийняття щодо неї законного та обгрунтованого рішення, та відповідного поновлення прав й законних інтересів осіб [7, с. 451].

Широкий перелік державних органів, управомочених здійснювати цивільно-правовий захист прав учасників кредитних відносин дає змогу стверджувати, що споживачі фінансових послуг вправі самостійно обирати будь-які передбачені законом 
способи захисту своїх прав та реалізовувати їх у відповідній формі. Позитивним задля досягнення бажаного результату буде як застосування засобів самозахисту, так і звернення до державних органів, що сприятимуть процесу реалізації захисту порушених прав. Водночас, варто зауважити, що в Україні існують й інші (не державні) органи, що здійснюють функції захисту прав учасників кредитних відносин. Ними є третейські суди, медіатори та ін. [5].

Аналізуючи зазначені вище способи захисту, що можуть бути використані споживачами фінансових послуг для реалізації своїх правових інтересів, можна виділити три групи таких засобів. До першої відноситься самозахист; до другої - способи, що можуть використовуються уповноваженим суб'єктом самостійно або за допомогою юрисдикційних органів; третю групу складають способи захисту, що можуть реалізовуватись виключно в межах компетенції спеціальних органів державної влади [6, с. 7-9]. Зокрема, визнання недійсним чи незаконним акту органу державної влади або місцевого самоврядування, що завдають шкоду правам та законним інтересам правомочних суб'єктів, може встановлюватись тільки за рішенням суду; такий засіб забезпечення виконання договору, як сплата неустойки, може встановлюватись у кредитному договорі або застосовуватись у судовому порядку; адміністративні санкції зможуть застосовуватись компетентними органами влади, а заходи оперативного впливу самою управомоченою особою [2, с. 46].

Зі сказаного можна зробити висновок, що реалізація учасниками кредитних відносин права на захист здійснюється: 1) у позовній формі; 2) у формі окремого або наказного провадження (наприклад справи про банкрутство, про стягнення заборгованості 3 юридичних осіб та фізичних осіб підприємців); 3) у адміністративній формі; 4) у неюрисдикційній формі [1]. Остання як раз таки передбачає застосування управомоченою особою можливостей досудового способу відновлення порушеного права (ст. 19 ЦПК України). Наприклад, він реалізується у випадку, коли кредитор звертається до боржника з вимогою добровільно виконати порушені умови договірного зобов'язання або розірвати його. Також досудовими способами захисту буде звернення споживача фінансових послуг до нотаріуса з письмовою заявою про вчинення відповідних нотаріальних дій, а також та можливість оскарження відмови посадової особи від вчинення таких дій.

Засоби правової охорони прав учасників кредитних відносин можна поділити на матеріальні та процесуальні. Вибір конкретного способу залежить від мети, яку прагнуть досягти управомочені суб'єкти. Серед матеріальних виділяються запобіжні, відновлювальні та штрафні способи захисту. Перші спрямовані на припинення неправомірних дій, що завдають шкоду або створюють загрозу реалізації суб’єктивних цивільних прав. Відновлювальні допомагають встановити факт наявності цивільного права, яке існувало до моменту вчинення правопорушення. Наприклад, визнання недійсним правочину, примусове виконання обов'язків у натурі, відшкодування моральної шкоди та збитків, тощо. Штрафні способи захисту цивільних прав застосовуються у випадку вчинення правопорушення та спрямовані компенсувати його наслідки. До них можна віднести сплату процентів за неправомірне користування чужими коштами, стягнення неустойки [4].

Процесуальні способи захисту становлять собою передбачені законодавством дії судових органів, що реалізуються в межах їх компетенції та за умови дотримання встановленої процедури здійснення. До них відносяться законодавчі приписи, що визначають порядок розгляду справи, винесення судового рішення, види таких рішень, їх форму та зміст. Вони становлять собою акти застосування матеріально-правових норм, що приймаються юрисдикційними органами у встановленому процесуальним законодавством порядку [4, с. 18]. Цивільні процесуальні способи захисту розрізняються залежно від виду судового рішення, специфіки відповідних категорій справ, тощо. Наприклад, за видом та метою відновлення порушеного права вони можуть поділятись на акти, спрямовані на визнання суб'єктивного права, примушення до вико- 


\section{Цивільне, підприсмницьке, господарське та трудове право}

нання обов'язків, зміна чи припинення правовідносин тощо.

У науковій юридичній доктрині можна зустріти позиції науковців стосовно поділу способів захисту суб'єктивних цивільних прав на загальні, спеціальні та окремі. Перші - це ті, що передбачені загальноправовими нормами, другі - спеціальними нормативно-правовими актами, присвяченими регулюванню окремих видів цивільних відносин. Останні способи захисту встановлюються самими сторонами у відповідному договорі [10, с. 360]. Багатьма правниками підтримується висновок про можливість поділу загальних способів захисту цивільних прав на три групи, що здійснюється за критерієм правового результату, на досягнення якого вони спрямовані. Зокрема, виділяють способи, що використовуються для посвідчення суб'єктивного права. До них можуть бути віднесені такі засоби захисту, як визнання права, примусове виконання, визнання незаконним акту державного органу або органу місцевого самоврядування, їх посадових осіб. Вказані способи об'єднуються за правовими наслідками їх використання. Так, примус до виконання обов'язку в натурі випливає з посвідчення у правомочного суб'єкта права на відповідні вимоги. Аналізуючи українську судову практику, можна зробити висновок, що вищезазначені правозахисні дії вчиняються учасниками відповідних відносин першочергово та передують застосуванню інших способів захисту.

Також до універсальних засобів захисту варто віднести так звані попереджувальні способи, що спрямовані на недопущення правопорушень та їх припинення. Наприклад, до них можна віднести встановлення в договору такого способу забезпечення виконання зобов'язання, як стягнення неустойки та інших видів цивільної відповідальності. Такі способи покликані стимулювати боржника до належного виконання зобов'язання або припинення його порушення.

Останню групу загальних способів захисту суб'єктивних цивільних прав утворюють засоби, спрямовані на відновлення права та компенсацію збитків. До них відносяться визнання недійсним правочину, відновлення стану, який існував до моменту вчинення правопорушення, відшкодування моральної шкоди та майнової шкоди.

\section{Висновки}

3 наведеного вище вбачається, що система способів захисту прав споживачів фінансових послуг становить собою внутрішньо упорядковану сукупність всіх чинних способів захисту, які можна систематизувати шляхом використання різних наукових класифікацій. Так, за формою вони поділяються на юрисдикційні та неюрисдикційні; за суб’єктами реалізації виділяють судові, адміністративні способи та самозахист; за рівнем самостійності та спрямованістю реалізації - ті, що правомочна особа здійснює самостійно, та ті, що можуть застосовуватись тільки спеціально-уповноваженими органами державної влади; за стадіями виникнення - досудові та судові, останні в свою чергу поділяються на ті, що здійснюються у позовному провадженні, у наказному провадженні, а також окремо виділяють способи, що реалізуються в адміністративному порядку; за напрямками правового впливу на кредитні відносини розрізняють способи захисту прав їх учасників, що спрямовані на засвідчення суб'єктивного права, на попередження чи припинення порушення та на відновлення прав; за юридичною підставою виникнення способи захисту поділяють на загальні, спеціальні та окремі.

\section{Аітература}

1. Васильев С. В. Особливості розгляду окремих категорій цивільних справ : навч. посіб. Харків : Еспада, 2012. 480 с.

2. Господарський кодекс України. Науково-практичний коментар / за ред. О. І. Харитонової. Харків : Одіссей, 2007. $832 \mathrm{c}$.

3. Петруня В. В. Поняття та система способів захисту прав суб'єктів господарювання : автореф. дис ... канд. юрид. наук : 12.00.04 / Нац. ун-т «Одес. юрид. акад.». Одеса, 2019. 20 с.

4. Притика Ю. Д. Поняття і диференціація способів захисту цивільних прав та інтересів. Вісник Київського національного університету імені Тараса Шевченка. Серія: Юридичні науки. 2004. Вип. 60-62. С. 16-19. 


\section{АНОТАЦІЯ}

У статті аналізується стан ицивільно-правового захисту прав фбізичних осіб - позичальників у кредитних відносинах на сучасному етапі розвитку вітчизняного законодавства. Доводиться, що система способів захисту прав споживачів фбінансових послуг становить собою внутрішнъо упорядковану сукупність усіх існуючих засобів, які можна систематизувати шляхом використання різних наукових класифікаиій. Аргументується достовірність поділу досліджуваних способів захисту на дві групи: юрисдикційні та неюрисдикиійні. Аналізуються положення начіонального ии вільного законодавства України та робиться висновок про варіативність способів захисту прав споживачів бінансових послуг залежно від суб'єкта реалізаий правової охорони. Досліджуються судові, адміністративні способи та засоби самозахисту прав учасників кредитних відносин. Доводиться необхідність надання бізичній особі - споживачу бінансових послуг певних додаткових засобів захисту, що призведе бактичної рівності учасників кредитування.

Ключові слова: Позика, кредит, захист изивільних прав, міри ичивільно-правової відповідальності, споживачі бонансових послуг.

5. Про третейські суди : Закон України від 11.05.2014 р. № 1701-IV. Відомості Верховної Ради України. 2004. № 35. Ст. 412.

6. Стоякин Г. Я. Меры защиты в советском гражданском праве : автореф. дис. ... канд. юрид. наук : 12.00 .03 / Свердлов. юрид. ин-т. Свердловск, 1973. 22 с.

7. Хозяйственное право Украины : учебник / под ред.: А. С. Васильев, О. П. Подцерковный. 3-е изд., перераб. и доп. Харьков : Одиссей, 2008. 488 с.

8. Цивільний кодекс України [Електронний ресурс]: Закон України від 16.01.2003,

SUMMARY
The article analyzes the state of civil
law protection of the rights of individuals -
borrowers in credit relations at the present stage
of development of domestic legislation. It turns
out that the system of ways to protect the rights of
consumers of financial services is an internally
organized set of all existing tools that can be
systematized through the use of various scientific
classifications. The reliability of the division of
the studied methods of protection into two groups
is argued: jurisdictional and non-jurisdictional.
The provisions of the national civil legislation
of Ukraine are analyzed and a conclusion is
made about the variability of ways to protect
the rights of consumers of financial services
depending on the subject of legal protection.
Judicial, administrative methods and means of
self-defense of the rights of participants in credit
relations are studied. It is necessary to provide a
natural person - consumer of financial services
with certain additional means of protection,
which will lead to the de facto equality of credit
participants.
Key words: loan, credit, protection of civil
rights, measures of civil liability, consumers of
financial services.

№ 435-IV // Верховна Рада України : офіц. веб-портал. - Режим доступу: https://zakon. rada.gov.ua/laws/show/435-15\#n2644 (дата звернення: 21.02.2016). - Заголовок з екрана.

9. Цивільний кодекс України : наук.практ. комент. у 2 ч. / за заг. ред. Я. М. Шевченко. Київ : Ін Юре, 2004. Ч. 1. 692 с.

10. Шишка Р. Б. Охорона права інтелектуальної власності: авторсько-правовий аспект : монографія. Харків : Вид-во Нац. ун-ту внутр. справ, 2002. 386 c. 